\title{
The Use of Insecticide Mosquito Nets and Insecticide Spraying on the Risk of Malaria in Children: A Meta-Analysis
}

\author{
Arlina Azka'), Setyo Sri Rahardjo²), Bhisma Murti1) \\ ${ }^{1)}$ Masters Program in Public Health, Universitas Sebelas Maret \\ ${ }^{2)}$ Faculty of Medicine, Universitas Sebelas Maret
}

\section{ABSTRACT}

Background: Malaria is a vector-borne disease caused by Plasmodium infection and there are more than 30 species of Anopheles which are important vectors of malaria. The main interventions recommended for controlling malaria vectors are the use of insecticide mosquito nets and indoor residual spraying. This study aims to estimate the effect of using insecticide mosquito nets and spraying insecticides on the risk of malaria in children.

Subjects and Method: This was a meta-analysis study using PRISMA flow diagram guidelines. Article searches were carried out in the PubMed, Google Scholar, Science Direct, ResearchGate, and SpringerLink databases with the keywords "risk factor" OR determinant AND malaria AND "insecticide treated net" OR "insecticide treated bednets" OR "bed net" OR "indoor spraying" OR "insecticide spraying" OR "indoor residual spraying" AND "toddlers". The study problem is formulated by using the PICO model: the population are toddlers, the sleep intervention using insecticide mosquito nets and lives in homes receiving insecticide spraying, comparison is sleeping without using insecticide mosquito nets and living in homes that do not receive insecticides, and the outcome is malaria. Inclusion criteria include full-text articles with cross-sectional design, published in 2010-2021, and there are multivariate analysis results in the form of adjusted odds ratio values. Data were analyzed using RevMan 5.3 application.

Results: Fourteen articles from Tanzania, Nigeria, Uganda, Rwanda, Burkina Faso, Zambia, Malawi, Cameroon, Ethiopia, the Democratic Republic of Congo, and other countries in SubSaharan Africa shows that children who sleep using insecticide net have a lower risk by $15 \%$ to become infected with malaria ( $\mathrm{aOR}=0.85$; CI $95 \%=0.75$ to $0.98 ; \mathrm{p}=0.020)$. Eight research articles from Zambia, Tanzania, Uganda, Nigeria, Sierra Leone, and Ethiopia showed that children living in homes sprayed with insecticides have lower risk by $37 \%$ to become infected with malaria $(\mathrm{aOR}=0.63$; CI 95\%=0.49 to $0.79 ; \mathrm{p}<0.001)$.

Conclusion: The use of insecticide mosquito nets and insecticide spraying reduces the risk of malaria in children.

Keywords: insecticide mosquito nets, insecticide spraying, malaria, children

\section{Correspondence:}

Arlina Azka. Masters Program in Public Health, Universitas Sebelas Maret. Jalan Ir. Sutami 36A, Surakarta 57126, Central Java. Email: arlina.azka@gmail.com. Phone: +628121477366o.

Cite this as:

Azka A, Rahardjo SR, Murti B (2021). The Use of Insecticide Mosquito Nets and Insecticide Spraying on the Risk of Malaria in Children: A Meta-Analysis. J Epidemiol and Public Health. 06(03): 320-332. https://doi.org/10.26911/jepublichealth.2021.06.03.06.

(c) (7) (2) Journal of Epidemiology and Public Health is licensed under a Creative Commons Attribution-NonCommercial-ShareAlike 4.0 International License.

\section{BACKGROUND}

Malaria is an infectious disease caused by the plasmodium parasite and is transmitted through the bite of a female Anopheles sp infected vector by plasmodium. Nearly half of the world's population is at risk of becoming infected with malaria (WHO, 2021). The global malaria incidence in 2019 was 57 per 1,000 population at risk. The mortality rate for toddlers is still quite high, 
which reaching $67 \%$ of the total 409,000 deaths in 2019 (WHO, 2020).

The distribution of cases and the level of malaria endemicity are strongly influenced by the presence of the infectious vector. There are more than 400 species of Anopheles mosquitoes in the world and about 30 of them are important vectors of malaria (WHO, 2021). These mosquitoes begin to bite actively soon after dark, with high biting activity that differs for each species and is influenced by geographic location (Debebe et al., 2018). The presence of adult Anopheles activity in the house at night indicates the need for using insecticide mosquito nets for sleeping and spraying insecticides inside the house (Animut and Negash, 2018).

The use of insecticide nets and indoor residual spraying are the main interventions in malaria control that are recommended for all at-risk populations (WHO, 2019). This method is effective in preventing malaria transmission and reducing deaths. Based on estimates of the annual number of clinical malaria cases prevented by vector control interventions in Madagascar, the use of mosquito nets and insecticide spraying was able to prevent more than 100,000 cases in one year. There are $88 \%$ of cases thatcan be prevented by using insecticide-treated mosquito nets and as many as $12 \%$ of cases can be prevented by spraying insecticides (Kesteman et al., 2016).

The use of insecticide nets and insecticide spraying has been shown to have an effect on malaria infection. Comprehensive research and sourced from various primary studies is needed to estimate the magnitude of the influence of these two factors. This study aims to estimate the effect of using insecticide mosquito nets and insecticide spraying on the risk of malaria in children.

\section{SUBJECTS AND METHOD}

\section{Study Design}

This study uses a systematic review and meta-analysis design. Article searches were conducted on several databases, including PubMed, Google Scholar, Science Direct, ResearchGate, and SpringerLink. The keywords used are "risk factor" OR determinant AND malaria AND "insecticide treated net" OR "insecticide treated bednets" OR "bed net" OR "indoor spraying" OR "insecticide spraying" OR "indoor residual spraying" AND "toddlers".

\section{Inclusion Criteria}

The inclusion criteria used are full-text articles with cross-sectional design, published from 2010 to 2021, and there are multivariate analysis results in the form of adjusted odds ratio values.

\section{Exclusion Criteria}

The exclusion criteria in this study were articles that were not in English and Indonesian and articles that had been included in the previous meta-analysis.

\section{Operational Definition}

The study problem in this meta-analysis is formulated in the PICO model. The study population are toddlers. The interventions are sleeping using an insecticide mosquito net and staying at home with insecticide spraying (indoor residual spraying) with a comparison of sleeping without an insecticide mosquito net and staying at home that did not receive insecticide spraying. The study outcome is the incidence of malaria.

The use of insecticide net is children ho sleep under an insecticide mosquito net attached to the bed at least the night before the investigation.

Insecticide spraying is spraying insecticide liquid on walls or other surfaces in the house at least once in the last 12 months before the study is carried out. 
Azka et al./ The Use of Insecticide Mosquito Nets and Insecticide Spraying on the Risk of Malaria

Malaria is a plasmodium parasite infection that causes symptoms or does not cause symptoms, which is known through blood examination and the presence of malaria parasites or malaria parasite antigens in the blood is found.

\section{Study Instrument}

The study was conducted according to the PRISMA flow diagram guidelines and the assessment of study quality was carried out using a critical appraisal for cross-sectional study checklist from the Center for Evidence-Based Management (CEBMa, 2014).

\section{Data Analysis}

The study data were analyzed by using the RevMan 5.3 application by calculating the effect size and heterogeneity of the study data to determine the analytical model used, namely the random effect model or the fixed effect model. The results are presented in the form of forest plots and funnel plots.

\section{RESULTS}

The process of selecting and reviewing articles using the PRISMA flow diagram can be seen in Figure 1. A total of 16 articles sourced from the African continent were declared eligible and included in this metaanalysis.

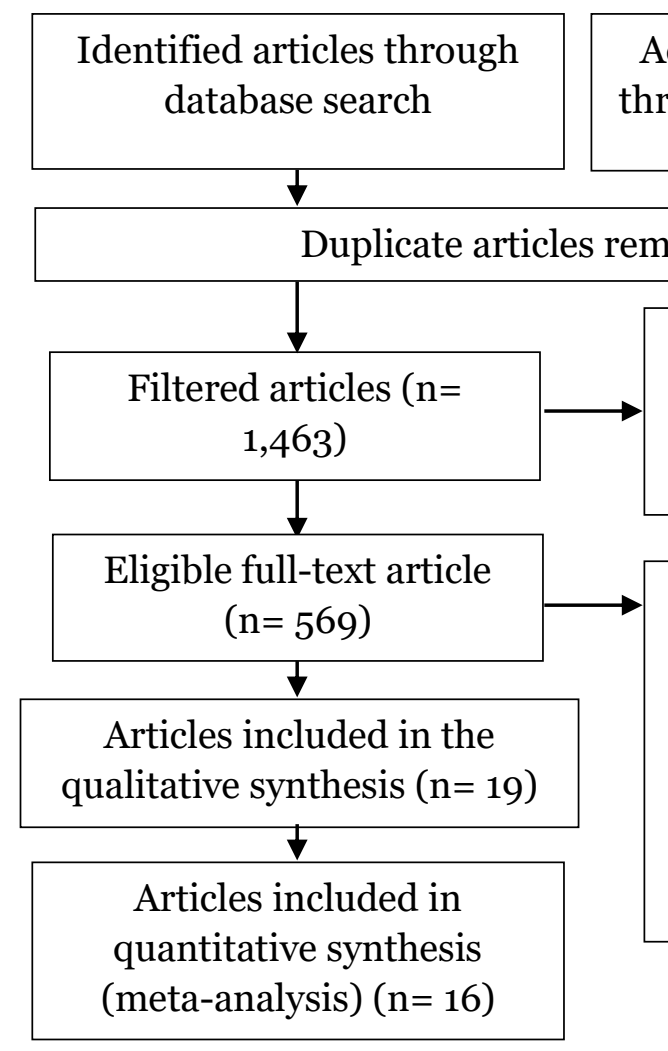

Additional identified articles

through other databases $(n=9)$

shed articles $(n=894)$

1. Non full-text articles $=296$

2. Not in English or Indonesian $=2$

3. Irrelevant title $=596$

Full-text article issued with reason $(\mathrm{n}=550)$

1. The design is not cross-sectional $=122$

2. The population are not toddlers $=102$

3. The outcome is not malaria incidence $=137$

4. Intervention is not the use of insecticide mosquito nets or insecticide spraying $=86$

5. Data analysis is not logistic regression $=69$

6. $\mathrm{aOR}$ is not available $=34$

\section{Figure 1. PRISMA flow diagram}

1. The effect of using insecticide mosquito nets on the risk of malaria in children
A total of 14 articles from Tanzania, Nigeria, Uganda, Rwanda, Burkina Faso, Zambia, Malawi, Cameroon, Ethiopia, Democratic Republic of Congo, and other 
Azka et al./ The Use of Insecticide Mosquito Nets and Insecticide Spraying on the Risk of Malaria

countries in Sub-Saharan Africa were included in the meta-analysis (see Table 1 and 2). Based on the forest plot (Figure 2), the results showed that children who slept using insecticide mosquito nets had a $15 \%$ lower risk of becoming infected with malaria than children who slept without using insecticides mosquito nets $(\mathrm{aOR}=$ $0.85 ; 95 \% \mathrm{CI}=0.75$ to $0.98 ; \mathrm{p}=0.020$ ). The funnel plot (Figure 3) showed that there was a publication bias in this study which was known from the asymmetric distribution of the plots. The estimated effect size on the effect of using insecticide-treated bed nets on the risk of malaria in children exceeded the actual effect size (overestimate).

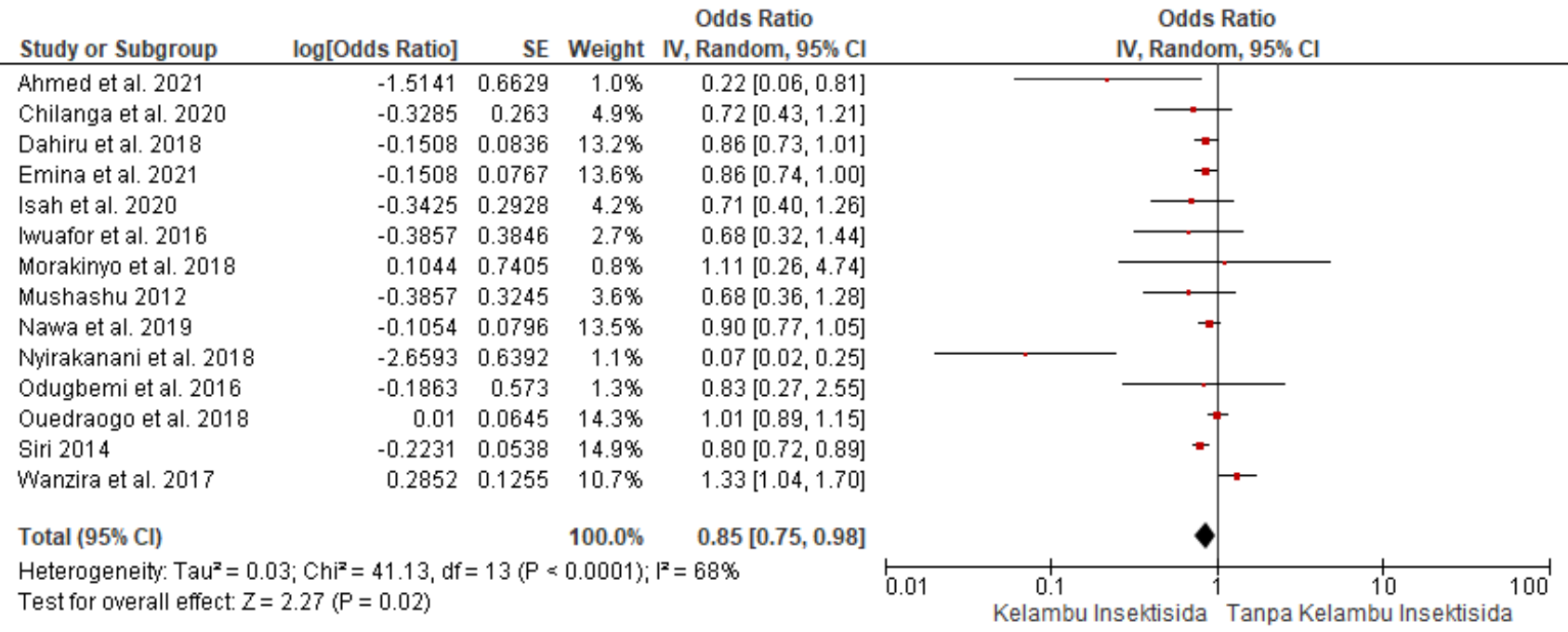

Figure 2. Forest Plot of the effect of using insecticide mosquito nets on the risk of malaria in children

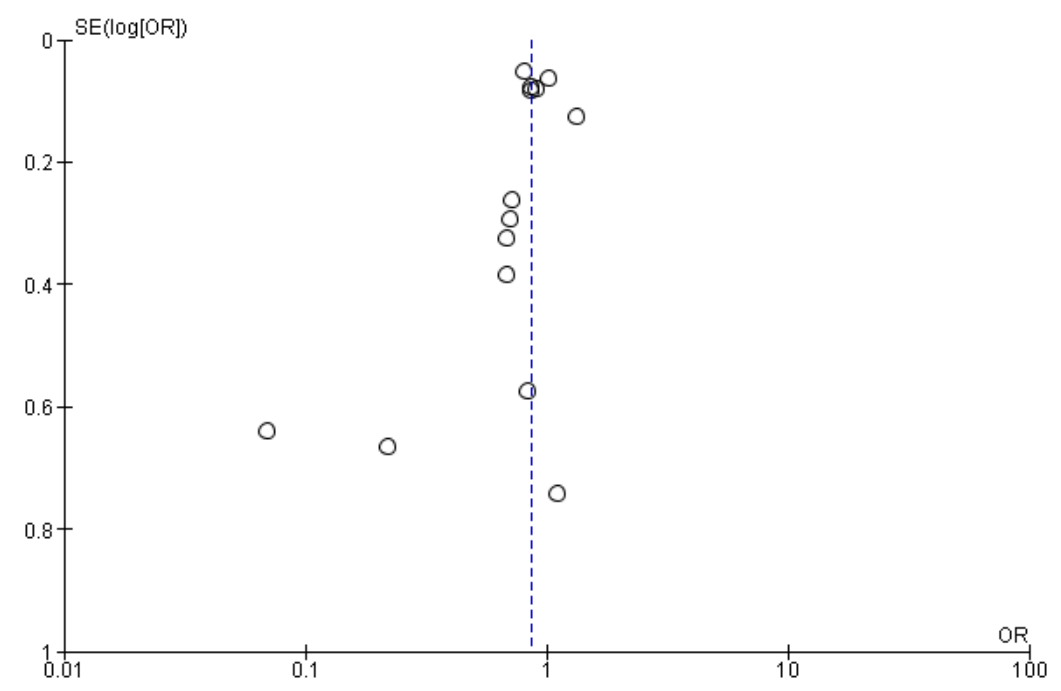

Figure 3. Funnel plot of the effect of using insecticide mosquito nets on the risk of malaria in children 
Table 1. Description of the primary article on the use of insecticide mosquito nets

\begin{tabular}{|c|c|c|c|c|c|c|c|}
\hline $\begin{array}{c}\text { Author } \\
\text { (year) }\end{array}$ & Country & $\begin{array}{l}\text { Study } \\
\text { Design }\end{array}$ & Sample & $\begin{array}{c}\mathbf{P} \\
\text { Population }\end{array}$ & $\begin{array}{c}\text { I } \\
\text { Intervention }\end{array}$ & $\begin{array}{c}\mathrm{C} \\
\text { Comparison }\end{array}$ & $\begin{array}{c}O \\
\text { Outcome and Instrument }\end{array}$ \\
\hline $\begin{array}{l}\text { Mushashu } \\
\text { (2012) }\end{array}$ & Tanzania & $\begin{array}{l}\text { Cross- } \\
\text { sectional }\end{array}$ & 391 & Toddlres & $\begin{array}{l}\text { Using insecticide } \\
\text { mosquito nets }\end{array}$ & $\begin{array}{l}\text { Not using insec- } \\
\text { ticide mosquito nets }\end{array}$ & $\begin{array}{l}\text { Malaria } \\
\text { Rapid Diagnostic Test (RDT) }\end{array}$ \\
\hline Siri (2014) & $\begin{array}{l}\text { Countries in Sub- } \\
\text { Saharan Africa } \\
\text { (Angola, Liberia, } \\
\text { Uganda, Malawi, } \\
\text { Rwanda, Senegal, } \\
\text { Tanzania, Nigeria } \\
\text { and Madagascar) }\end{array}$ & $\begin{array}{l}\text { Cross- } \\
\text { sectional }\end{array}$ & 34,137 & Toddlres & $\begin{array}{l}\text { Children sleep using } \\
\text { insecticide mosquito } \\
\text { nets }\end{array}$ & $\begin{array}{l}\text { Children sleep } \\
\text { without using } \\
\text { insecticide } \\
\text { mosquito nets }\end{array}$ & $\begin{array}{l}\text { Malaria } \\
\text { Blood laboratory tests }\end{array}$ \\
\hline $\begin{array}{l}\text { Iwuafor et al. } \\
\text { (2016) }\end{array}$ & Nigeria & $\begin{array}{l}\text { Cross- } \\
\text { sectional }\end{array}$ & 270 & Toddlres & $\begin{array}{l}\text { Using insecticide } \\
\text { mosquito nets }\end{array}$ & $\begin{array}{l}\text { Not using } \\
\text { insecticide } \\
\text { mosquito nets }\end{array}$ & $\begin{array}{l}\text { Malaria } \\
\text { Microscopic examination of } \\
\text { thick and thin blood smears }\end{array}$ \\
\hline $\begin{array}{l}\text { Odugbemi et } \\
\text { al. (2016) }\end{array}$ & Nigeria & $\begin{array}{l}\text { Cross- } \\
\text { sectional }\end{array}$ & 480 & Toddlres & $\begin{array}{l}\text { Using insecticide } \\
\text { mosquito nets }\end{array}$ & $\begin{array}{l}\text { Not using } \\
\text { insecticide } \\
\text { mosquito nets }\end{array}$ & $\begin{array}{l}\text { Malaria } \\
\text { Rapid Diagnostic Test (RDT) }\end{array}$ \\
\hline $\begin{array}{l}\text { Wanzira et al. } \\
\text { (2017) }\end{array}$ & Uganda & $\begin{array}{l}\text { Cross- } \\
\text { sectional }\end{array}$ & 4,930 & Toddlres & $\begin{array}{l}\text { Using insecticide } \\
\text { mosquito nets }\end{array}$ & $\begin{array}{l}\text { Not using } \\
\text { insecticide } \\
\text { mosquito nets }\end{array}$ & $\begin{array}{l}\text { Malaria } \\
\text { Microscopic examination of } \\
\text { thick and thin blood smears }\end{array}$ \\
\hline $\begin{array}{l}\text { Dahiru et al. } \\
\text { (2018) }\end{array}$ & Nigeria & $\begin{array}{l}\text { Cross- } \\
\text { sectional }\end{array}$ & 6,632 & $\begin{array}{l}\text { Children aged } \\
6-59 \text { months }\end{array}$ & $\begin{array}{l}\text { Children sleep using } \\
\text { insecticide mosquito } \\
\text { nets }\end{array}$ & $\begin{array}{l}\text { Not using } \\
\text { insecticide } \\
\text { mosquito nets }\end{array}$ & $\begin{array}{l}\text { Malaria } \\
\text { Microscopic examination }\end{array}$ \\
\hline $\begin{array}{l}\text { Morakinyo et } \\
\text { al. (2018) }\end{array}$ & Nigeria & $\begin{array}{l}\text { Cross- } \\
\text { sectional }\end{array}$ & 6,991 & $\begin{array}{l}\text { Children aged } \\
6-59 \text { months }\end{array}$ & $\begin{array}{l}\text { Using insecticide } \\
\text { mosquito nets }\end{array}$ & $\begin{array}{l}\text { Not using } \\
\text { insecticide } \\
\text { mosquito nets }\end{array}$ & $\begin{array}{l}\text { Malaria } \\
\text { Microscopic examination of } \\
\text { thick and thin blood smears }\end{array}$ \\
\hline
\end{tabular}


Table 2. Next

\begin{tabular}{|c|c|c|c|c|c|c|c|}
\hline $\begin{array}{l}\text { Author } \\
\text { (Year) }\end{array}$ & Country & $\begin{array}{c}\text { Study } \\
\text { Design }\end{array}$ & Sample & $\begin{array}{c}\mathbf{P} \\
\text { Population } \\
\end{array}$ & $\begin{array}{c}\text { I } \\
\text { Intervention } \\
\end{array}$ & $\begin{array}{c}\mathrm{C} \\
\text { Comparison } \\
\end{array}$ & $\begin{array}{c}\mathrm{O} \\
\text { Outcome and Instrument }\end{array}$ \\
\hline $\begin{array}{l}\text { Nyirakanani et } \\
\text { al. (2018) }\end{array}$ & Rwanda & $\begin{array}{l}\text { Cross- } \\
\text { sectional }\end{array}$ & 222 & Toddlres & $\begin{array}{l}\text { Using insecticide } \\
\text { mosquito nets }\end{array}$ & $\begin{array}{l}\text { Not using insecticide } \\
\text { mosquito nets }\end{array}$ & $\begin{array}{l}\text { Malaria } \\
\text { Microscopic examination of } \\
\text { thick blood smears }\end{array}$ \\
\hline $\begin{array}{l}\text { Ouédraogo et } \\
\text { al. (2018) }\end{array}$ & $\begin{array}{l}\text { Burkina } \\
\text { Faso }\end{array}$ & $\begin{array}{l}\text { Cross- } \\
\text { sectional }\end{array}$ & 10,245 & Toddlres & $\begin{array}{l}\text { Using insecticide } \\
\text { mosquito nets }\end{array}$ & $\begin{array}{l}\text { Not using insecticide } \\
\text { mosquito nets }\end{array}$ & $\begin{array}{l}\text { Malaria } \\
\text { Rapid Diagnostic Test (RDT) }\end{array}$ \\
\hline $\begin{array}{l}\text { Nawa et al. } \\
(2019)\end{array}$ & Zambia & $\begin{array}{l}\text { Cross- } \\
\text { sectional }\end{array}$ & 10,131 & Toddlres & $\begin{array}{l}\text { Using insecticide } \\
\text { mosquito nets }\end{array}$ & $\begin{array}{l}\text { Not using insecticide } \\
\text { mosquito nets }\end{array}$ & $\begin{array}{l}\text { Malaria } \\
\text { Microscopic examination }\end{array}$ \\
\hline $\begin{array}{l}\text { Chilanga et al. } \\
(2020)\end{array}$ & Malawi & $\begin{array}{l}\text { Cross- } \\
\text { sectional }\end{array}$ & 523 & $\begin{array}{l}\text { Children aged } \\
\text { 2-59 months }\end{array}$ & $\begin{array}{l}\text { Using insecticide } \\
\text { mosquito nets }\end{array}$ & $\begin{array}{l}\text { Not using insecticide } \\
\text { mosquito nets }\end{array}$ & $\begin{array}{l}\text { Malaria } \\
\text { Rapid Diagnostic Test (RDT) }\end{array}$ \\
\hline $\begin{array}{l}\text { Isah et al. } \\
(2020)\end{array}$ & Cameroon & $\begin{array}{l}\text { Cross- } \\
\text { sectional }\end{array}$ & 391 & Toddlres & $\begin{array}{l}\text { Using insecticide } \\
\text { mosquito nets }\end{array}$ & $\begin{array}{l}\text { Not using insecticide } \\
\text { mosquito nets }\end{array}$ & $\begin{array}{l}\text { Malaria } \\
\text { Microscopic examination of } \\
\text { thick blood smears }\end{array}$ \\
\hline $\begin{array}{l}\text { Ahmed et al. } \\
\text { (2021) }\end{array}$ & Ethiopia & $\begin{array}{l}\text { Cross- } \\
\text { sectional }\end{array}$ & 356 & Toddlres & $\begin{array}{l}\text { Using insecticide } \\
\text { mosquito nets }\end{array}$ & $\begin{array}{l}\text { Not using insecticide } \\
\text { mosquito nets }\end{array}$ & $\begin{array}{l}\text { Malaria } \\
\text { Rapid Diagnostic Test (RDT) }\end{array}$ \\
\hline $\begin{array}{l}\text { Emina et al. } \\
(2021)\end{array}$ & $\begin{array}{l}\text { Democratic } \\
\text { Republic of } \\
\text { Congo }\end{array}$ & $\begin{array}{l}\text { Cross- } \\
\text { sectional }\end{array}$ & 8,547 & $\begin{array}{l}\text { Children agd 6- } \\
59 \text { months }\end{array}$ & $\begin{array}{l}\text { Using insecticide } \\
\text { mosquito nets }\end{array}$ & $\begin{array}{l}\text { Not using insecticide } \\
\text { mosquito nets at } \\
\text { night }\end{array}$ & $\begin{array}{l}\text { Malaria } \\
\text { Microscopic examination of } \\
\text { thick blood smears }\end{array}$ \\
\hline
\end{tabular}


Azka et al./ The Use of Insecticide Mosquito Nets and Insecticide Spraying on the Risk of Malaria

2. The effect of insecticide spraying on the risk of malaria in children

A total of 8 study articles from Zambia, Tanzania, Uganda, Nigeria, Sierra Leone, and Ethiopia were included in the metaanalysis (see Table 3). The forest plot (Figure 4) showed that children living in homes that were sprayed with insecticides had a $37 \%$ less risk of becoming infected with malaria than children who lived in homes without insecticides spraying ( $\mathrm{aOR}=$ $0.63 ; 95 \% \mathrm{CI}=0.49$ to $0.79 ; \mathrm{p}<0.001)$. In the funnel plot (Figure 5), it is known that the distribution of the plot is asymmetric which indicates a slight publication bias. The estimated effect size on the effect of insecticide spraying on the risk of malaria in children exceeded the actual effect size (overestimate).

\begin{tabular}{|c|c|c|c|c|c|c|c|c|c|}
\hline Study or Subgroup & log[Odds Ratio] & SE & Weight & $\begin{array}{c}\text { Odds Ratio } \\
\text { IV, Fixed, } 95 \% \mathrm{Cl}\end{array}$ & & \multicolumn{3}{|c|}{$\begin{array}{c}\text { Odds Ratio } \\
\text { IV, Fixed, } 95 \% \mathrm{Cl}\end{array}$} & \\
\hline Ahmed et al. 2021 & -0.734 & 0.9142 & $1.7 \%$ & \multicolumn{2}{|l|}{$0.48[0.08,2.88]$} & & & & \\
\hline Bah 2020 & -0.5798 & 0.4115 & $8.4 \%$ & \multicolumn{2}{|l|}{$0.56[0.25,1.25]$} & & & & \\
\hline Dahiru et al. 2018 & -1.7148 & 0.7674 & $2.4 \%$ & \multicolumn{2}{|l|}{$0.18[0.04,0.81]$} & & & & \\
\hline Morakinyo et al. 2018 & -0.1863 & 0.3355 & $12.6 \%$ & \multicolumn{2}{|l|}{$0.83[0.43,1.60]$} & & & & \\
\hline Mushashu 2012 & -0.5447 & 0.4946 & $5.8 \%$ & \multicolumn{2}{|l|}{$0.58[0.22,1.53]$} & & & & \\
\hline Nawa et al. 2019 & -0.4155 & 0.152 & $61.5 \%$ & \multicolumn{2}{|l|}{$0.66[0.49,0.89]$} & & 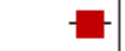 & & \\
\hline Riedel et al. 2010 & 0.5481 & 0.7223 & $2.7 \%$ & \multicolumn{2}{|l|}{$1.73[0.42,7.13]$} & & & & \\
\hline Wanzira et al. 2017 & -1.4697 & 0.5388 & $4.9 \%$ & \multicolumn{2}{|l|}{$0.23[0.08,0.66]$} & & & & \\
\hline \multicolumn{2}{|l|}{ Total $(95 \% \mathrm{Cl})$} & & $100.0 \%$ & \multicolumn{2}{|l|}{$0.63[0.49,0.79]$} & & & & \\
\hline \multicolumn{4}{|c|}{$\begin{array}{l}\text { Heterogeneity: } \mathrm{Chi}^{2}=9.08, \mathrm{df}=7(\mathrm{P}=0.25) ; \mathrm{I}^{2}=23 \% \\
\text { Test for overall effect: } Z=3.94(P<0.0001)\end{array}$} & & 0.01 & 0.1 & $\operatorname{IRS}^{1}$ & Non-IRS & 100 \\
\hline
\end{tabular}

Figure 4. Forest Plot of the Effect of Insecticide Spraying (Indoor Residual Spraying) on the Risk of Malaria in Children

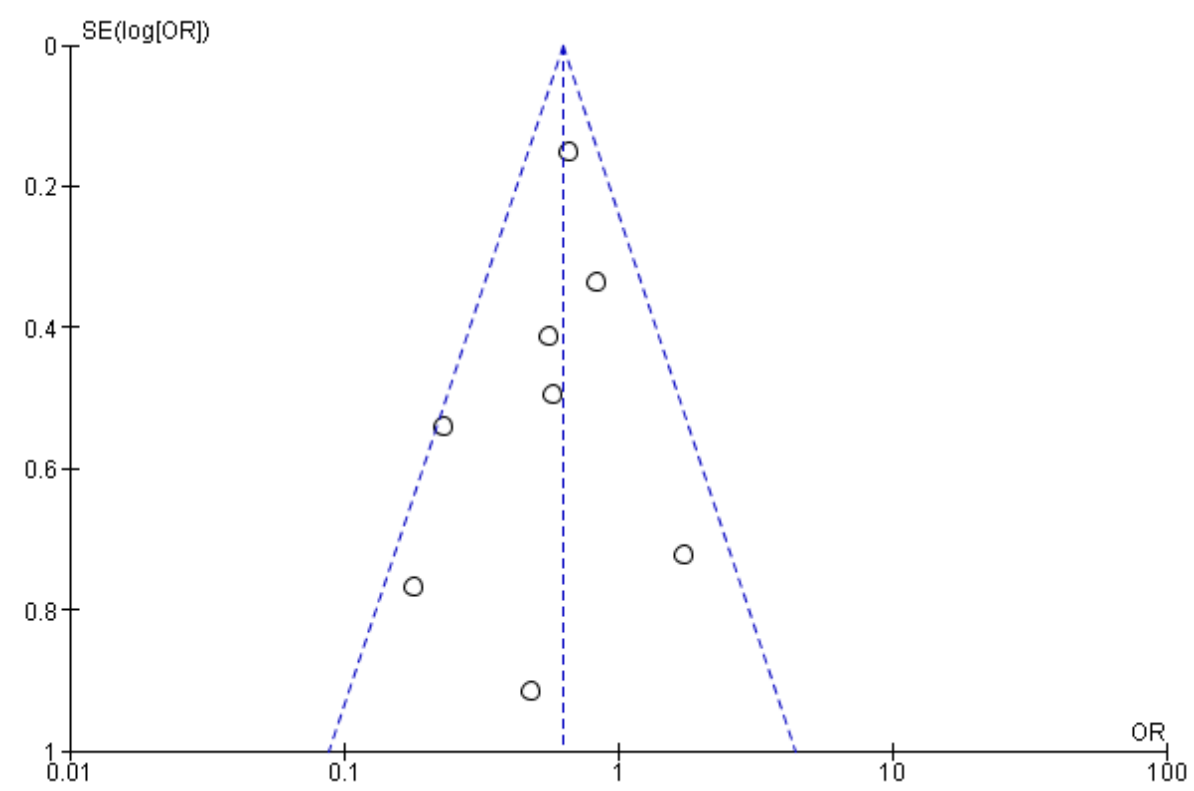

Figure 5. Funnel Plot of the Effect of Insecticide Spraying (Indoor Residual Spraying) on the Risk of Malaria in Children 
Table 3. Primary article description of insecticide spraying

\begin{tabular}{|c|c|c|c|c|c|c|c|}
\hline $\begin{array}{l}\text { Author } \\
\text { (year) }\end{array}$ & Country & $\begin{array}{l}\text { Study } \\
\text { Design }\end{array}$ & Sample & $\begin{array}{c}\mathbf{P} \\
\text { Population }\end{array}$ & $\begin{array}{c}\text { I } \\
\text { Intervention }\end{array}$ & $\begin{array}{c}\mathrm{C} \\
\text { Comparison }\end{array}$ & $\begin{array}{c}\text { O } \\
\text { Outcome and Instrument }\end{array}$ \\
\hline $\begin{array}{l}\text { Riedel et al. } \\
(2010)\end{array}$ & Zambia & $\begin{array}{l}\text { Cross- } \\
\text { sectional }\end{array}$ & 1,324 & Toddlers & $\begin{array}{l}\text { House has been } \\
\text { sprayed with } \\
\text { insecticide in the last } \\
12 \text { months }\end{array}$ & $\begin{array}{l}\text { The house has not been } \\
\text { sprayed with insecticide } \\
\text { in the last } 12 \text { months }\end{array}$ & $\begin{array}{l}\text { Malaria } \\
\text { Rapid Diagnostic Test (RDT) } \\
\text { with Paracheck Pf }\end{array}$ \\
\hline $\begin{array}{l}\text { Mushashu } \\
\text { (2012) }\end{array}$ & Tanzania & $\begin{array}{l}\text { Cross- } \\
\text { sectional }\end{array}$ & 391 & Toddlers & $\begin{array}{l}\text { The house is sprayed } \\
\text { with insecticide }\end{array}$ & $\begin{array}{l}\text { The house is not } \\
\text { sprayed with insecticide }\end{array}$ & $\begin{array}{l}\text { Malaria } \\
\text { Rapid Diagnostic Test (RDT) }\end{array}$ \\
\hline $\begin{array}{l}\text { Wanzira et } \\
\text { al. (2017) }\end{array}$ & Uganda & $\begin{array}{l}\text { Cross- } \\
\text { sectional }\end{array}$ & 4,930 & Toddlers & $\begin{array}{l}\text { The house has been } \\
\text { sprayed with } \\
\text { insecticide in the last } \\
6 \text { months }\end{array}$ & $\begin{array}{l}\text { The house has not been } \\
\text { sprayed with insecticide } \\
\text { in the last } 6 \text { months }\end{array}$ & $\begin{array}{l}\text { Malaria } \\
\text { Microscopic examination of } \\
\text { thick and thin blood smears }\end{array}$ \\
\hline $\begin{array}{l}\text { Dahiru et } \\
\text { al. (2018) }\end{array}$ & Nigeria & $\begin{array}{l}\text { Cross- } \\
\text { sectional }\end{array}$ & 6,632 & $\begin{array}{l}\text { Children aged } \\
6-59 \text { months }\end{array}$ & $\begin{array}{l}\text { The house has been } \\
\text { sprayed with } \\
\text { insecticide in the last } \\
12 \text { months }\end{array}$ & $\begin{array}{l}\text { The house has not been } \\
\text { sprayed with insecticide } \\
\text { in the last } 12 \text { months }\end{array}$ & $\begin{array}{l}\text { Malaria } \\
\text { Microscopic examination }\end{array}$ \\
\hline $\begin{array}{l}\text { Morakinyo } \\
\text { et al. } \\
\text { (2018) }\end{array}$ & Nigeria & $\begin{array}{l}\text { Cross- } \\
\text { sectional }\end{array}$ & 6,991 & Toddlers & $\begin{array}{l}\text { The house has been } \\
\text { sprayed with } \\
\text { insecticide in the last } \\
12 \text { months }\end{array}$ & $\begin{array}{l}\text { The house has not been } \\
\text { sprayed with insecticide } \\
\text { in the last } 12 \text { months }\end{array}$ & $\begin{array}{l}\text { Malaria } \\
\text { Microscopic examination of } \\
\text { thick and thin blood smears }\end{array}$ \\
\hline $\begin{array}{l}\text { Nawa et al. } \\
\text { (2019) }\end{array}$ & Zambia & $\begin{array}{l}\text { Cross- } \\
\text { sectional }\end{array}$ & 10,131 & Toddlers & $\begin{array}{l}\text { The house is sprayed } \\
\text { with insecticide }\end{array}$ & $\begin{array}{l}\text { The house is not } \\
\text { sprayed with insecticide }\end{array}$ & $\begin{array}{l}\text { Malaria } \\
\text { Microscopic examination }\end{array}$ \\
\hline $\mathrm{Bah}(2020)$ & $\begin{array}{l}\text { Sierra } \\
\text { Leone }\end{array}$ & $\begin{array}{l}\text { Cross- } \\
\text { sectional }\end{array}$ & 6,715 & $\begin{array}{l}\text { Children aged } \\
\text { o-59 months }\end{array}$ & $\begin{array}{l}\text { The house has been } \\
\text { sprayed with } \\
\text { insecticide in the last } \\
12 \text { months }\end{array}$ & $\begin{array}{l}\text { The house has not been } \\
\text { sprayed with insecticide } \\
\text { in the last } 12 \text { months }\end{array}$ & $\begin{array}{l}\text { Malaria } \\
\text { Microscopic examination of } \\
\text { thick and thin blood smears }\end{array}$ \\
\hline $\begin{array}{l}\text { Ahmed et } \\
\text { al. (2021) }\end{array}$ & Ethiopia & $\begin{array}{l}\text { Cross- } \\
\text { sectional }\end{array}$ & 356 & Toddlers & $\begin{array}{l}\text { The house has been } \\
\text { sprayed with } \\
\text { insecticide in the last } \\
6 \text { months }\end{array}$ & $\begin{array}{l}\text { The house has not been } \\
\text { sprayed with insecticide } \\
\text { in the last } 6 \text { months }\end{array}$ & $\begin{array}{l}\text { Malaria } \\
\text { Rapid Diagnostic Test (RDT) }\end{array}$ \\
\hline
\end{tabular}


Azka et al./ The Use of Insecticide Mosquito Nets and Insecticide Spraying on the Risk of Malaria

\section{DISCUSSION}

This study is a systematic and metaanalysis study with the theme of the effect of using insecticide mosquito nets and spraying insecticides on the risk of malaria. Eligible primary study results were combined and statistically analyzed to estimate the influence of the independent variables on the effect of using insecticide mosquito nets and spraying insecticides and the dependent variable on malaria in children.

Based on age, toddlers were significantly 2.40 times more likely to be infected with malaria parasites compared to adults ( $\mathrm{aOR}=2.40 ; 95 \% \mathrm{CI}=1.72$ to 3.35 ) (Gimnig et al., 2016). Malaria has an impact on the growth, development and general health of the children. Malaria infection increased the risk for stunting $(\mathrm{aOR}=1.9 ; 95 \% \mathrm{CI}=1.2$ to 2.9) and wasting (aOR=8.5; 95\% $\mathrm{CI}=5.0$ to 14.5) (Gari et al., 2018). Impaired growth and development is associated with anemia in children infected with malaria (Milner et al., 2020).

There are many factors that influence the incidence of malaria. Malaria infection was independently associated with the height of residence, the quality of the house structure, access to adequate mosquito nets per bed, the use of protective clothing at night, activities outside the house at night, and the presence of potential breeding grounds for mosquitoes around the house (Tesfahunegn et al., 2019; Mosha et al., 2020).

The analysis result of the primary study of the effect of using insecticidetreated bed nets on the risk of malaria in children showed that children who slept using insecticide mosquito nets had a $15 \%$ less risk of becoming infected with malaria than children who slept without using insecticide nets $(\mathrm{aOR}=0.85 ; 95 \% \mathrm{CI}=0.75$ to $0.98 ; \mathrm{p}=0.020)$. Ashton et al. (2020) states that children who sleep using insecticide mosquito nets have a $43 \%$ lower risk of becoming infected with malaria than children who sleep without using insecticide mosquito nets $(\mathrm{aOR}=0.57 ; 95 \% \mathrm{CI}=$ 0.37 to 0.90 ). The use of insecticide mosquito nets reduces the risk of contact between children and mosquitoes. Reduction of the entomological index of mosquito density and human contact is associated with long-term use of insecticide mosquito nets (Mutuku et al., 2011).

Malaria vectors are able to detect insecticide mosquito nets from a distance. The insect olfactory system has a high sensitivity, therefore, it is possible that the concentration of insecticide in the air around the mosquito net can be detected by mosquitoes (Moiroux et al., 2017).

Although the nature of insecticide nets is to prevent individuals from contracting malaria, the use of insecticide nets can help prevent further transmission to household members and the closest community indirectly so that it has an impact on the community level (Fullman et al., 2013; Steinhardt et al., 2013).

Another finding in this meta-analysis was that children living in houses that were sprayed with insecticides had a 37\% lower risk of becoming infected with malaria than children who lived in houses without insecticides spraying $(\mathrm{aOR}=0.63 ; 95 \% \mathrm{CI}=0.49$ to $0.79 ; \mathrm{p}<0.001)$. Gimnig et al. (2016) stated that after two rounds of insecticide spraying, malaria parasitaemia infection was significantly $56 \%$ lower in those who received insecticide spraying compared to those who did not $(\mathrm{aOR}=0.44 ; 95 \% \mathrm{CI}=$ 0.24 to 0.80 ). In addition, clinical malaria infection was also $53 \%$ lower in those who received insecticide sprays compared to those who did not $(\mathrm{aOR}=0.47 ; 95 \% \mathrm{CI}=$ 0.24 to 0.93 ). 
Azka et al./ The Use of Insecticide Mosquito Nets and Insecticide Spraying on the Risk of Malaria

Insecticides spraying can protect people from mosquitoes by preventing malaria mosquitoes from entering the house or killing mosquitoes when mosquitoes are resting on walls after sucking the blood (Fullman et al., 2013). Insecticides spraying has an excito-repellent effect, insecticides that are sprayed protect family members who live in the house by preventing mosquitoes from entering the house through direct contact with vapor particles at a distance (Briët et al., 2019).

The use of insecticides in controlling mosquito populations has proven to be effective but has negative impacts that need to be considered so that risks can be minimized or suppressed. Children who sleep under insecticide mosquito nets and live in homes that have been sprayed with insecticides are at risk of exposure to insecticide residues through inhalation (inhaling volatile residues), skin contact (touching residues on surfaces), and hand-to-mouth contact, thereby increasing the risk of ingesting residues (Moreno- Gómez et al., 2021). The application of insecticides with appropriate procedures, techniques, tools, and doses according to recommenddations can reduce the risk of health hazards to humans and the environment (WHO, 2015; Damalas and Koutroubas, 2016).

The use of insecticides in controlling mosquito populations has proven to be effective but has negative impacts that need to be considered so that risks can be minimized or suppressed. Children who sleep under insecticide mosquito nets and live in houses that have been sprayed with insecticides are at risk of exposure to insecticide residues through inhalation (inhaling volatile residues), skin contact (touching residues on surfaces), and hand-to-mouth contact, thereby increasing the risk of ingesting residues (Moreno- Gómez et al., 2021). The application of insecticides with appropriate procedures, techniques, tools and doses according to recommenddations can reduce the risk of health hazards to humans and the environment (WHO, 2015; Damalas and Koutroubas, 2016) (WHO, 2015).

\section{AUTHORS CONTRIBUTION}

Arlina Azka is the main researcher who selected the topic, searched for and collected the data. Setyo Sri Rahardjo and Bhisma Murti analyzed the data and reviewed the documents.

\section{FUNDING AND SPONSORSHIP}

This study is a self-funded study.

\section{CONFLICT OF INTEREST}

None.

\section{ACKNOWLEDGEMENT}

The research would like to thank to database providers including PubMed, Google Scholar, Science Direct, ResearchGate and SpringerLink.

\section{REFERENCES}

Ahmed A, Mulatu K, Elfu B (2021). Prevalence of malaria and associated factors among under-five children in Sherkole refugee camp, BenishangulGumuz region, Ethiopia. A crosssectional study. PLoS One, 16(2): 1-8. doi: 10.1371/journal.pone.0246895.

Animut A, Negash Y (2018). Dry season occurrence of Anopheles mosquitoes and implications in Jabi Tehnan District, West Gojjam Zone, Ethiopia. Malar J, 17(1). doi: 10.1186/s12936018-2599-4.

Ashton RA, Joseph V, Hoogen LL VD, Tetteh KKA, Stresman G, Worges M, Druetz T, et al. (2020). risk factors for malaria infection and seropositivity in the elimination area of Grand'Anse, Haiti: A case-control 
Azka et al./ The Use of Insecticide Mosquito Nets and Insecticide Spraying on the Risk of Malaria

study among febrile individuals seeking treatment at Public Health Facilities. Am J Trop Med Hyg, 103(2): 767-777. doi: 10.4269/AJTMH.200097.

Bah MS (2020). The relationship between malaria status in under-five children and some household demographic, socioeconomic and environmental factors associated with the disease in Sierra Leone. Thesis. Georgia State University.

Briët OJT, Impoinvil DE, Chitnis N, Pothin E, Lemoine JF, Frederic J, Smith TA (2019). Models of effectiveness of interventions against malaria transmitted by Anopheles albimanus. Malar J. 18(1): 1-12. doi: 10.1186/S12936-019-2899-3/FIGURES/7.

CEBMa (2014). critical appraisal for crosssectional study. Center for EvidenceBased Management. Available at: https://cebma.org/wp-content/uploads/Critical-Appraisal-Questionsfor-a-Cross-Sectional-Study-July2014-1.pdf (Accessed: May 7, 2021).

Chilanga E, Collin-Vézina D, MacIntosh H, Mitchell C, Cherney K (2020). Prevalence and determinants of malaria infection among children of local farmers in Central Malawi. Malar J. 19(1). doi: 10.1186/S12936-020-03382-7.

Dahiru T, Alhaji A, Ahmadu L, Oyefabi M (2018). Determinants of childhood malaria morbidities in Nigeria: secondary analysis of 2015 malaria indicator survey. Int $J$ Trop Dis Heal. 31(1): 1-15. doi: 10.9734/IJTDH/20$18 / 40520$.

Damalas CA, Koutroubas SD (2016). Farmers' exposure to pesticides: toxicity types and ways of prevention. Toxics. 4(1): 1. doi: 10.3390/TOXICS4010001.
Debebe Y, Hill SR, Tekie H, Ignell R, Hopkins RJ (2018). Shady business: Understanding the spatial ecology of exophilic Anopheles mosquitoes. Malar J. 17(1). doi: 10.1186/s12936-0182499-7.

Emina JBO, Doctor H V, Yé Y (2021). Profiling malaria infection among under-five children in the Democratic Republic of Congo. PLoS One. 16(5 May): 1-21. doi: 10.1371/journal.pone.0250550.

Fullman N, Burstein R, Lim SS, Medlin C, Gakidou E (2013). Nets, spray or both? the effectiveness of insecticidetreated nets and indoor residual spraying in reducing malaria morbidity and child mortality in subSaharan Africa. Malar J. 12(1). doi: 10.1186/1475-2875-12-62.

Gari T, Loha E, Deressa W, Solomon T, Lindtjørn B (2018). Malaria increaseed the risk of stunting and wasting among young children in Ethiopia: Results of a cohort study. PLoS One. 13(1). doi: 10.1371/JOURNAL.PONE.0190983 .

Gimnig JE, Otieno P, Were V, Marwanga D, Abong'o D, Wiegand R, Williamson J, et al. (2016). The effect of indoor residual spraying on the prevalence of malaria parasite infection, clinical malaria and anemia in an area of perennial transmission and moderate coverage of insecticide treated nets in western Kenya. PLoS One, 11(1). doi: 10.1371/JOURNAL.PONE.0145282.

Isah M, Ambe NF, Bobga TP, Ketum AS, Ivan MK, Abungwi MA (2020). Predictors of malaria prevalence and coverage of insecticide-treated bednets among under-five children in the Buea Health District, South West Region, Cameroon. J Biosci Med. 
Azka et al./ The Use of Insecticide Mosquito Nets and Insecticide Spraying on the Risk of Malaria

o8(o2): 25-40. doi: 10.4236/jbm.2020.82003 .

Iwuafor AA, Egwuatu CC, Nnachi AU, Ita IO, Ogban GI, Akujobi CN, Egwuatu TO (2016). Malaria parasitaemia and the use of insecticide-treated nets (INTs) for malaria control amongst under-5year old children in Calabar, Nigeria. BMC Infect Dis. 16(1): 1-12. doi: 10.1186/s12879-016-1459-5.

Kesteman T, Randrianarivelojosia M, Raharimanga V, Randrianasolo L, Piola P, Rogier C (2016). Effectiveness of malaria control interventions in Madagascar: A nationwide casecontrol survey. Malar J. 15(1): 1-10. doi: 10.1186/s12936-016-1132-x.

Mahkota R, Nurcandra F, Anggraini FDP, Putri AI, Wispriyono B (2020). Risk of agricultural pesticide exposure to malaria incidence and anopheles susceptibility at an endemic area in Central Java, Indonesia-A Case-control Study. Maced J Med Sci. 8(E): 52-59. doi: 10.3889/oamjms.2020.3024.

Milner EM, Kariger P, Pickering AJ, Stewart $\mathrm{CP}$, Byrd $\mathrm{K}$, Lin A, Rao G, et al. (2020). association between malaria infection and early childhood development mediated by anemia in Rural Kenya. Int $\mathrm{J}$ Environ Res Public Health. 17(3): 902. doi: 10.3390/IJERPH17030902.

Moiroux N, Chandre F, Hougard J-M, Corbel V, Pennetier C (2017). Remote Effect of Insecticide-Treated Nets and the Personal Protection against Malaria Mosquito Bites. PLoS One, 12(1): e0170732. doi: 10.1371/JOURNAL.PONE.0170732.

Morakinyo OM, Balogun FM, Fagbamigbe AF (2018). Housing type and risk of malaria among under-five children in Nigeria: Evidence from the malaria indicator survey. Malar J, 17(1). doi: 10.1186/S12936-018-2463-6.

Moreno-Gómez M, Miranda MA, BuenoMarí R (2021). To kill or to repel mosquitoes? Exploring two strategies for protecting humans and reducing vector-borne disease risks by using pyrethroids as spatial repellents. Pathogens. 10(9): 1171. doi: 10.3390/PATHOGENS10091171.

Mosha JF, Lukole E, Charlwood JD, Wright A, Rowland M, Bullock O, Manjurano A, et al. (2020). Risk factors for malaria infection prevalence and household vector density between mass distribution campaigns of long-lasting insecticidal nets in North-western Tanzania. Malar J. 19(1): 1-11. doi: 10.1186/S12936-02o-03369-4.

Mushashu U (2012). Prevalence of malaria infection among under-fives and the associated factors in Muleba districtKagera region Tanzania. Thesis. Muhimbili University of Health and Allied Sciences.

Mutuku FM, King CH, Mungai P, Mbogo C, Mwangangi J, Muchiri EM, Walker $\mathrm{ED}$, et al. (2011). Impact of insecticide-treated bed nets on malaria transmission indices on the south coast of Kenya. Malar J. 10(1): 1-14. doi: 10.1186/1475-2875-10-356.

Nawa M, Hangoma P, Morse AP, Michelo $C$ (2019). Investigating the upsurge of malaria prevalence in Zambia between 2010 and 2015: A decomposition of determinants. Malar J. 18(1). doi: 10.1186/s12936-019-2698-x.

Nyirakanani C, Chibvongodze R, Habtu M, Masika M, Mukoko D, Njunwa KJ (2018). Prevalence and risk factors of asymptomatic malaria among underfive children in Huye District, South- 
Azka et al./ The Use of Insecticide Mosquito Nets and Insecticide Spraying on the Risk of Malaria

ern Rwanda. Tanzan J Health Res. 20(1): 1-7. doi: 10.4314/thrb.v20i1.6. Odugbemi BA, Wright KO, Onajole AT, Kuyinu YA, Goodman OO, Odugbemi TO, Odusanya OO (2016). A malariametric survey of under-fives residing in indoor residual spraying-implementing and non-implementing communities of Lagos, Nigeria. Malar J. 15(1). doi: 10.1186/S12936-016-1507$\mathrm{Z}$.

Ouédraogo M, Samadoulougou S, Rouamba T, Hien H, Sawadogo JEM, Tinto $\mathrm{H}$, Alegana VA, et al. (2018). Spatial distribution and determinants of asymptomatic malaria risk among children under 5 years in 24 districts in Burkina Faso. Malar J. 17(1): 1-12. doi: 10.1186/s12936-018-2606-9.

Rahayu N, Sulasmi S, Suryatinah Y (2017). Status kerentanan Ae. aegypti terhadap beberapa golongan insektisida di Provinsi Kalimantan Selatan (The vulnerability status of Ae. aegypti against several classes of insecticides in South Kalimantan Province). J Heal Epidemiol Commun Dis. 3(2): 56-62. doi: 10.22435/JHECDS.V3I2.1792 .

Riedel N, Vounatsou P, Miller JM, Gosoniu L, Chizema-Kawesha E, Mukonka V, Steketee RW (2010). Geographical patterns and predictors of malaria risk in Zambia: Bayesian geostatistical modelling of the 2006 Zambia national malaria indicator survey (ZMIS). Malar J, 9(1). doi: 10.1186/1475-2875-9-37.

Siri JG (2014). Independent Associations of Maternal Education and Household Wealth with Malaria Risk in Children. Ecol Soc, 19(1): 33.
Steinhardt LC, Yeka A, Nasr S, Wiegand RE, Rubahika D, Sserwanga A, Wanzira H, et al. (2013). The Effect of Indoor Residual Spraying on Malaria and Anemia in a High-Transmission Area of Northern Uganda. Am J Trop Med Hyg, 88(5): 855-861. doi: 10.4269/AJTMH.12-0747.

Tesfahunegn A, Berhe G, Gebregziabher E (2019). Risk factors associated with malaria outbreak in Laelay Adyabo district northern Ethiopia, 2017: case-control study design. BMC Public Health. 19(1): 1-7. doi: 10.1186/S12889-019-6798-X.

Wanzira H, Katamba H, Okullo AE, Agaba B, Kasule M, Rubahika D (2017). Factors associated with malaria parasitaemia among children under 5 years in Uganda: a secondary data analysis of the 2014 Malaria Indicator Survey dataset. Malar J. 16(1): 1-9. doi: 10.1186/s12936-017-1847-3.

WHO (2015). Indoor Residual Spraying: An Operational Manual for Indoor Residual Spraying (IRS) for Malaria Transmission Control and Elimination. Geneva: World Health Organization.

WHO (2019). Guidelines for malaria vector control. Geneva: World Health Organization.

WHO (2020). World Malaria Report 2020: 20 Years of Global Progress and Challenges. Geneva: World Health Organization.

WHO (2021). Malaria. Available at: https://www.who.int/news-room/ fact-sheets/detail/malaria (Accessed: April 5, 2021). 